\title{
Biochemical characterisation of lysozyme extracted from rainbow trout Oncorhynchus mykiss (Walbaum, 1792)
}

\author{
MARYAM MOHAMMAD GHOLIPOUR, ABBASS MORIDNIA* AND ZAHRA KHOSHNOOD \\ Department of Biology, Dezful Branch, Islamic Azad University, Dezful, Iran \\ *Department of Immunology, School of Medicine, Dezful University of Medical Sciences, Dezful, Iran \\ e-mail: zkhoshnood@gmail.com
}

\begin{abstract}
In the present study, lysozyme was extracted from spleen tissue of rainbow trout Oncorhynchus mykiss (Walbaum, 1792) and partially purified by ammonium sulfate precipitation. Optimum $\mathrm{pH}$ and temperature as well as effects of different salt concentrations of $\mathrm{NaCl}, \mathrm{MgCl}_{2}, \mathrm{KCl}$ and urea on enzyme activity were evaluated. The enzyme activity was assayed using a suspension of Micrococcus lysodeikticus as substrate. Results showed that lysozyme extracted from the spleen of $O$. mykiss has its optimum activity at high temperature $\left(60^{\circ} \mathrm{C}\right)$ and low $\mathrm{pH}(5.8)$ conditions and the enzyme activity was found to vary with different salt concentrations which were found related to the environmental conditions of natural habitats of $O$. mykiss.
\end{abstract}

Keywords: Enzymology, Immune System, Lysozyme, Rainbow trout

The first line of defense against infectious pathogens is provided by the non-specific immune responses or innate immune system (Abdollahi et al., 2016). The innate immune system is composed of two distinct parts: cellular and humoral. The mucus layer of fish is the first line of defense against pathogens (Gao, et al., 2016). Fish mucus layer has several hydrolytic enzymes including lysozyme, alkaline-phosphatase, Cathepsin-B and proteases (Subramanian et al., 2008). Mucus layer of skin which cover the scaled and non-scaled body parts plays its roles in defense by preventing pathogens from attachment, ion and osmoregulation and finally act as a reservoir of several innate immune factors such as lysozyme, immunoglobulins, complement proteins, lectins, C-reactive protein, proteolytic enzymes and different antibacterial proteins and peptides (Modanloo et al., 2017). It has been clearly demonstrated that fish mucus layer (on the skin, gill and in the intestine), is a key factor in immune responses (Ghalambor et al., 2020).

Adrenal gland and spleen are the other two parts of innate immunity in teleost fish (Grove et al., 2006). It has been previously documented that the fish adrenal gland and spleen are composed of immune cells with multiple sizes and roles, which are responsible in the secretion of humoral compounds including lysozyme and acid phosphatase (ACP) as important components of the innate immunity (Magnadottir, 2006). As mentioned above, one of the components of the humoral system is lysozyme which is known to have antibacterial activity by breaking down of the peptidoglycan bonds of the bacterial cell walls, especially in Gram-positive bacteria (Palaksha et al.,
2008). Lysozyme is found in invertebrates, vertebrates, plants and bacteria. Fish lysozyme is generally found in hematopoietic tissue of the head, kidney, spleen, skin, gill and digestive system. It has been demonstrated that, after incidents such as stress, injections of foreign materials or infections, the concentration of lysozyme increases in the fish body (Uribe et al., 2011).

Rainbow trout Oncorhynchus mykiss (Walbaum, 1792) belonging to the family Salmonidae is an economically and ecologically important fish species worldwide. This is one of the main aquacultured fish species and is spread in the vast majority of rivers and lakes all over the world. The aim of the present study was to evaluate the biochemical characteristics of lysozyme enzyme extracted from the spleen tissue of $O$. mykiss.

Fish were sampled from a fish farm at Dezful, Iran and 5 live adult $O$. mykiss (1-1.5 kg in body weight and $30-32 \mathrm{~cm}$ body length) were transferred to the laboratory and immediately submerged in a solution of clove oil as anesthetic and then dissected. Tissue samples of spleen, liver, gill and skin mucus were collected and after washing in physiological saline, the samples were stored in lysis buffer at $-70^{\circ} \mathrm{C}$ (Bazrkar and Aghamaali, 2015).

One gram each of the tissue sample and $1 \mathrm{~g}$ of skin mucus in lysis buffer was sonicated using a sonicater (BANDELINE HD2200) and then shaken for $1 \mathrm{~h}$ using Jeio Tech SK300. Subsequently, samples were centrifuged at $4^{\circ} \mathrm{C}$ at $5000 \mathrm{rpm}$ using Hettich UNIVERSAL 320R and the supernatant was collected. Samples were then analysed by SDS-PAGE using BioRad-Mini PROTEAN 
tetra system and based on the results obtained, spleen tissue was selected for continuing the study (Bazrkar and Aghamaali, 2015).

Spleen tissue ( $1 \mathrm{~g}$ ) was kept in $0.2 \mathrm{M}$ phosphate buffer ( $\mathrm{pH}$ 6.2) and then for complete lysis and homogenisation of the cells, samples were sonicated using BANDELINE HD2200. Samples were then centrifuged at $4000 \mathrm{rpm}$ at $4^{\circ} \mathrm{C}$ for $25 \mathrm{~min}$ using Hettich UNIVERSAL 320R. The supernatant $(4500 \mu \mathrm{l})$ was transferred to a new tube and kept at $-70^{\circ} \mathrm{C}$ for further evaluations (Bazrkar and Aghamaali, 2015). Ammonium sulfate $(1.68 \mathrm{~g})$ was added to $4500 \mu \mathrm{l}$ supernatant and then centrifuged at $9000 \mathrm{rpm}$ at $4^{\circ} \mathrm{C}$ for $15 \mathrm{~min}$. The supernatant was removed and the precipitate was used for subsequent evaluations. Sodium phosphate buffer $(0.2 \mathrm{M})$ was added to the precipitate and transferred to a dialysis bag with 21 of $30 \mathrm{mM}$ ammonium bicarbonate buffer and dialysed at $4^{\circ} \mathrm{C}$ for $36 \mathrm{~h}$. The sample was then lyophilised with ChristAlpha 1-2 LD plus and then $1 \mathrm{mg} \mathrm{ml}^{-1}$ concentration of the sample was dissolved in $0.1 \mathrm{M}$ phosphate buffer at $\mathrm{pH} 6.2$ and then stored at $-20^{\circ} \mathrm{C}$ as stock. Egg lysozyme (Sigma) was used as standard with a concentration of $1 \mathrm{mg} \mathrm{ml}^{-1}$ in $0.1 \mathrm{M}$ phosphate buffer (Bazrkar and Aghamaali, 2015).

To determine the effect of temperature on enzyme activity, Micrococcus lysodeikticus (Sigma) suspension was prepared by dissolving $0.0038 \mathrm{~g}$ of lyophilised powder of bacteria in $25 \mathrm{ml}$ of sodium phosphate buffer (pH 6.2) and $2.9 \mathrm{ml}$ each of the bacterial suspension was transferred to clean tubes. For each temperature, two tubes were used: standard tube containing egg lysozyme and the other one containing the sample. Each tube was examined at temperatures of $30,4045,50,55,60$ and $80^{\circ} \mathrm{C}$ and incubated in ben-Mari (Membert WNB14) for $50 \mathrm{~min}$. Enzyme kinetics was assayed using a spectrophotometer (Spectrum sp-uv200) at $450 \mathrm{~nm}$ for $3 \mathrm{~min}$ at intervals of $30 \mathrm{~s}$ (Bazrkar and Aghamaali, 2015).

Three different salts viz., $\mathrm{NaCl}, \mathrm{MgCl}_{2}$ and $\mathrm{KCl}$ were used to analyse the effects of salt concentrations on enzyme activity. Multiple concentrations from each salt were prepared at 20,40,60,80 and $100 \mathrm{mM}$. The bacterial suspension of $M$. lysodeikticus was prepared as described above and the suspension added to salt solutions and then optical absorption of each concentration was measured twice, first with standard (egg lysozyme) and second with the sample at $450 \mathrm{~nm}$ for $3 \mathrm{~min}$ at intervals of $30 \mathrm{~s}$ (Bazrkar and Aghamaali, 2015).

To evaluate the effects of urea concentration on enzyme activity, multiple concentrations of urea at 0.5 , 1.5, 2, 3 and $4 \mathrm{M}$ were prepared. Bacterial suspension of M. lysodeikticus $(2.9 \mathrm{ml}$ each) was then added to two micro-tubes, one containing standard egg lysozyme and the other containing the sample. The optical absorption of each concentration was measured at $450 \mathrm{~nm}$ for $3 \mathrm{~min}$ at intervals of $30 \mathrm{~s}$ (Bazrkar and Aghamaali, 2015).

In order to study the effects of $\mathrm{pH}$ on enzyme activity, the following buffers were prepared: Sodium acetate $(\mathrm{pH}=4)$; Sodium phosphate $(\mathrm{pH}=5.8)$; Sodium phosphate $(\mathrm{pH}=7)$; Sodium phosphate $(\mathrm{pH}=6.2)$ and Borate sodium ( $\mathrm{pH}$ 9). Bacterial suspension of $M$. lysodeikticus $(2.9 \mathrm{ml})$ was added to two micro-tubes, one containing standard egg lysozyme and the other containing the sample.. The optical density of each concentration was measured at $450 \mathrm{~nm}$ for $3 \mathrm{~min}$ at intervals of $30 \mathrm{~s} \mathrm{(Bazrkar}$ and Aghamaali, 2015).

In the present study, function and activity of the enzyme at different temperatures, multiple salt concentrations and multiple pHs were studied using the enzyme kinetic method by measuring the OD (optical density) at $450 \mathrm{~nm}$ at intervals of $30 \mathrm{~s}$ for $3 \mathrm{~min}$. Optical absorptions were then used in the following equation:

Unit per ml enzyme $=\frac{(\Delta \mathrm{A} 450 \mathrm{~nm} / \mathrm{min} \text { Test }-\Delta \mathrm{A} 450 \mathrm{~nm} / \mathrm{min} \text { Blank }) \mathrm{df}}{(0.001)(0.1)}$

where $\mathrm{df}=$ dilution factor; $0.001=$ change in absorbance at $\mathrm{A}_{450}$ as per the Unit Definition; $0.1=$ volume (in $\mathrm{ml}$ ) of enzyme used.

Mean and percentage values were calculated and analysed by MS Excel (Microsoft, 2010).

Innate immunity is essential for protection against pathogens. Several studies reviewed the immune system of the organisms with respect to the fact that lysozyme plays an important role in innate immunity (Abdollahi et al., 2016). For instance, Pabic et al. (2014) showed that in Sepia officinalis, lysozyme plays an important role in epithelial immune barriers, especially in the skin. Also, Panigrahi et al. (2004) showed that in case of infection, or in the presence of the pathogens, lysozyme levels increase in fish blood.

In the present study, analysis by SDS-PAGE was used for the determination of the suitable tissue for lysozyme extraction. SDS-PAGE at the reduction condition following Laemmli (1970) was used and protein bands were stained using coomassie brilliant blue (Fig. 1). The results showed that spleen is the main organ containing lysozyme enzyme in O. mykiss. Previous studies have shown that presence of lysozyme is higher in spleen and skin. Feng et al. (2011) and Caruso et al. (2012) demonstrated that lysozyme is essentially important in immunity against infections and increase/decrease in the concentration of lysozyme is dependent on fish species, gender, age and body weight. 


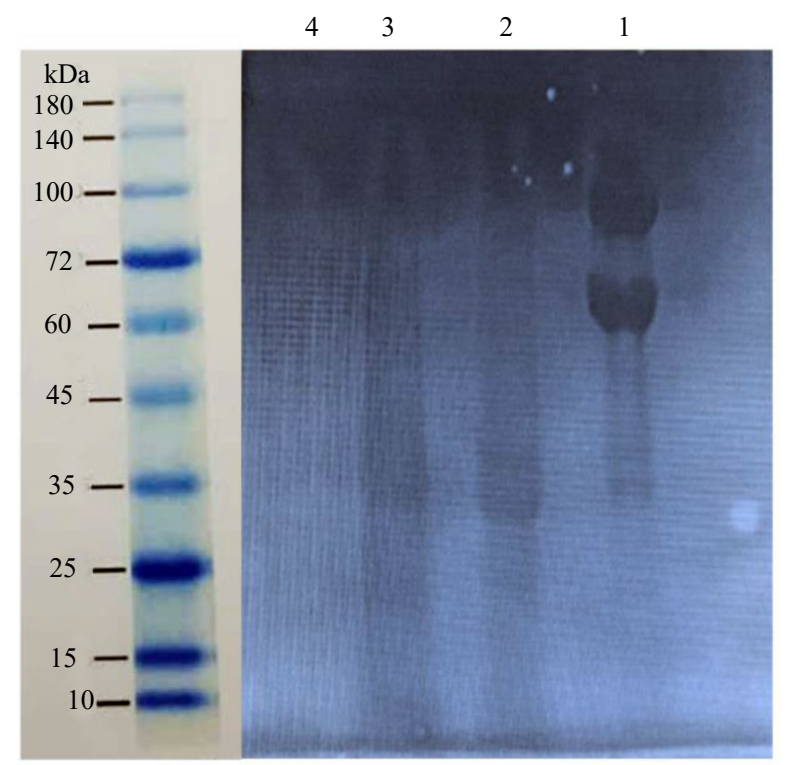

Fig. 1. SDS-PAGE image showing lysozyme content in the sampled tissues of the O. mykiss. Lanes 1: Liver; 2: Spleen; 3: Gill; 4: Skin mucus

Based on the results of electrophoresis, lysozyme was extracted from spleen tissue of rainbow trout and concentrated in $60 \%$ ammonium sulfate and finally, $40 \mathrm{mg}$ of protein was extracted. Results showed that the optimum temperature for maximum activity of the extracted lysozyme was $60^{\circ} \mathrm{C}$ after that temperature, enzyme activity drastically decreased (Fig. 2). On the other hand, the optimum $\mathrm{pH}$ for maximum enzyme activity was found to be 5.8 , beyond this $\mathrm{pH}$ enzyme activity decreased (Fig. 3). Results also showed that among the multiple concentrations of $\mathrm{NaCl}$, the maximum activity of the enzyme was recorded at $60 \mathrm{mM}$ (Fig. 4a). Furthermore, among the multiple concentrations of $\mathrm{KCl}$, the maximum activity of the enzyme was recorded at 40 $\mathrm{mM}$ and increase in salt concentration above this, the enzyme activity decreased (Fig. 4b). Besides, the effects of multiple concentrations of $\mathrm{MgCl}_{2}$ showed that the maximum activity of the extracted lysozyme was observed at $20 \mathrm{mM}$ (Fig. 4c). Results also showed that the maximum activity of the extracted lysozyme was observed at $4 \mathrm{mM}$ concentration of the denaturant urea (Fig. 4d).

Buonocore et al. (2014) studied molecular properties of the G-type lysozyme of the seabass, Dicentrarchus labrax and reported that the optimum activity of this lysozyme was at $\mathrm{pH} 5$ and at $30^{\circ} \mathrm{C}$, in presence of M. lysodeikticus as the substrate. In another study, Fujinami et al. (2014) extracted lysozyme from Cellana nigrolineata and showed that the activity of this lysozyme was higher than the activity of egg lysozyme by 43.3 folds. Optimum $\mathrm{pH}$ and temperature for the activity of

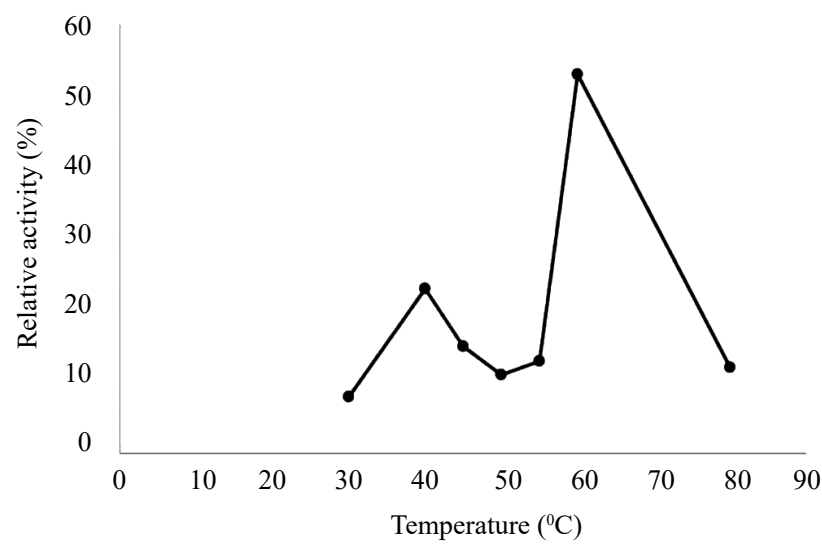

Fig. 2. Lysozyme relative activity (\%) from spleen of O. mykiss at different temperatures

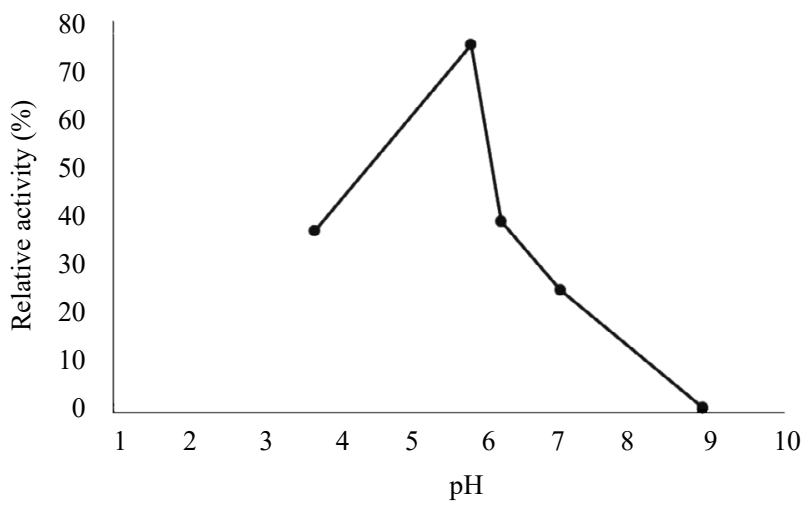

Fig. 3. Lysozyme relative activity (\%) from spleen of O. mykiss in relation to different $\mathrm{pH}$

C. nigrolineata lysozyme were 5 and $50^{\circ} \mathrm{C}$ respectively. Results of the present study showed that the optimum $\mathrm{pH}$ for extracted lysozyme from $O$. mykiss was 5.8. Previous studies have shown that lysozyme type $\mathrm{C}$ and $\mathrm{G}$ in Japanese flounder (Minagawa, 2001) and lysozyme type C of the Chlamys sp. (a marine invertebrate) (Nilsen, 1999) are active at acidic $\mathrm{pH}$.

Previous studies also showed that the optimum temperature for lysozyme activity in most fish is $30-50^{\circ} \mathrm{C}$ (Minagawa, 2001). Some studies showed an optimum temperature below this range, such as Lysozyme $\mathrm{G}$ of the flounder $\left(20-25^{\circ} \mathrm{C}\right)$ (Minagawa, 2001). In the present study, the optimum temperature for maximum activity of the lysozyme was observed at $60^{\circ} \mathrm{C}$.

Activity of the $O$. mykiss lysozyme was found to be dependent on salt concentrations $\left(\mathrm{NaCl}, \mathrm{KCl}\right.$ and $\left.\mathrm{MgCl}_{2}\right)$. Results of the previous studies on lysozyme extracted from Ruditapes philippinarum indicated that, with increase in the concentration of $\mathrm{NaCl}$ from $0-70 \mathrm{mM}$ and $\mathrm{MgCl}_{2}$ from 0-5 mM, the enzyme activity increased (Misook, 2012). 


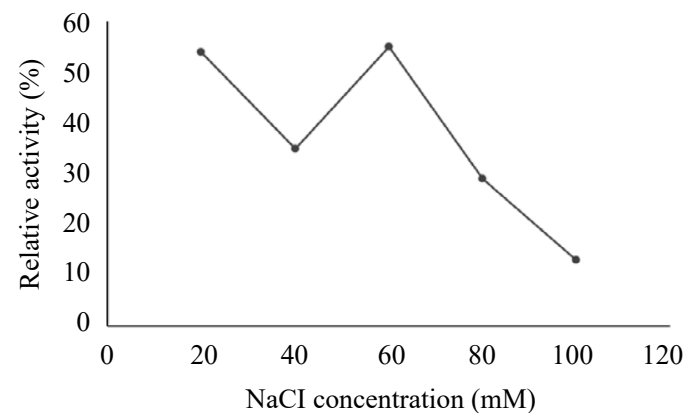

(a)

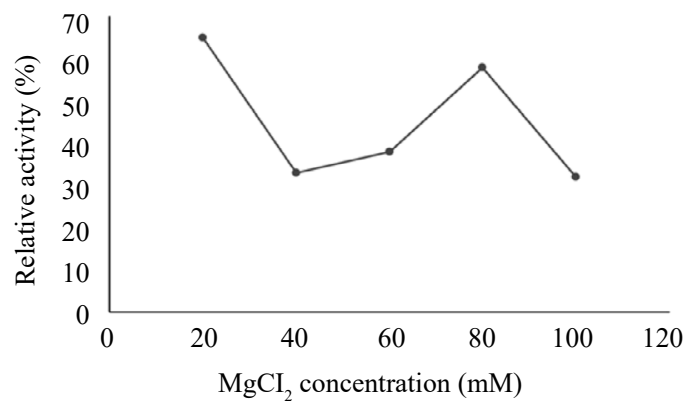

(c)

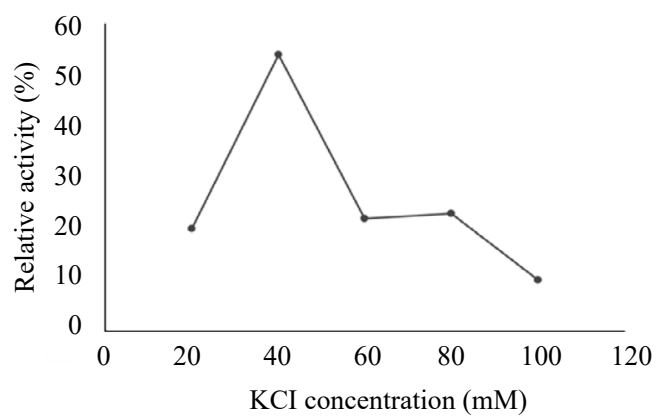

(b)

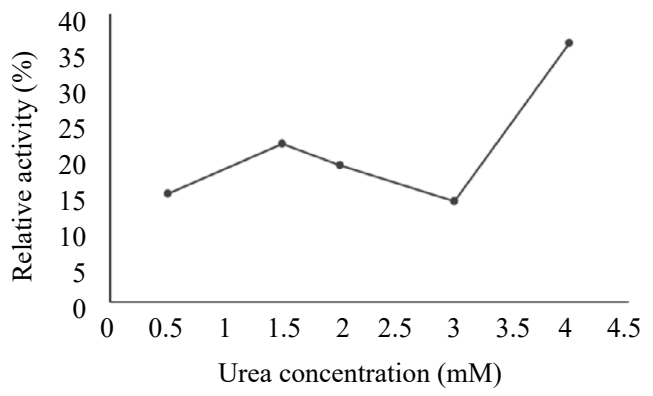

(d)

Fig. 4. Lysozyme relative activity (\%) from spleen of $O$. mykiss in relation to multiple concentrations of (a) $\mathrm{NaCl} ;$ (b) $\mathrm{KCl} ;\left(\right.$ c) $\mathrm{MgCl}{ }_{2}$ and (d) Urea

In the present study, maximum activity of the lysozyme was observed at the highest concentration of urea. Despite this finding, previous studies demonstrated that urea inhibited lysozyme activity (Sidhan, 1982; Bazrkar and Aghamaali, 2015). On the other hand, in another study on the effects of three different denaturants, guanidine thiocyanate, guanidine hydrochloride and urea, it has been observed that urea had the lowest effect on enzyme activity (Emadi and Behzadi, 2014).

Considering the results of the present study in comparison to that of previous studies, one could conclude that the lysozyme extracted from spleen of $O$. mykiss is a G-type lysozyme with its activity basically dependent on temperature, salt concentration and $\mathrm{pH}$.

\section{Acknowledgments}

We thank Dr. Eslamifar, Ms. Saneipour and Ms. Anaam for their valuable assistance with experimental techniques.

\section{References}

Abdollahi, R., Heidari, B. and Aghamaali, M. 2016. Evaluation of lysozyme, complement $\mathrm{C} 3$ and total protein in different developmental stages of Caspian kutum (Rutilus frisii kutum K.). Arch. Pol. Fish., 24(1): 15-22. DOI 10.1515/ aopf-2016-0002.
Bazrkar, V. and Aghamaali, M. 2015. Biochemical characterisation of lysozyme from Caspian kutum Rutilus frisii kutum. Aquac. Physiol. Biochem., 2(4): 23-33 (In Persian)

Buonocorea, F., Randellia, E., Trisolinoa, P., Facchianob, A., Pascalec, D. and Scapigliatiaa, G. 2014. Molecular characterization, gene structure and antibacterial activity of a g-type lysozyme from the European seabass (Dicentrarchus labrax L.). Mol. Immunol., 62(1): 10-18. doi: 10.1016/j.molimm.2014.05.009.

Caruso, G., Denaro, M. G., Caruso, R., Genovese, L., Mancari, F. and Maricc hiolo, G. 2012. Short fasting and refeeding in red porgy (Pagrus pagrus, Linnaeus 1758): Response of some haematological, biochemical and non-specific immune parameters. Mar. Environ. Res., 81: 18-25. https:// doi.org/10.1016/j.marenvres.2012.07.003.

Emadi, S. and Behzadi, M. 2014. A comparative study on the aggregating effects of guanidine thiocyanate, guanidine hydrochloride and urea on lysozyme aggregation. Biochem. Biophysic. Res. Commun., 450: 1339-1344. https://doi. org/10.1016/j.bbrc.2014.06.133.

Feng, G., Shi, X., Huang, X. and Zhuang, P. 2011. Oxidative stress and antioxidant defenses after long-term fasting in blood of Chinese sturgeon (Acipenser sinensis). Procedia. Enviromen. Sci., 8: 469-475. https://doi.org/10.1016/j. proenv.2011.10.074. 
Fujinami, N., Ikeda M., Miyauch, K. and Matsumiya, M. 2014. Purification and characterization of lysozyme from the black lined limpet Cellana nigrolineata. J. Chit. Chitos. Sci., 2(2): 157-161(5).

Gao, C., Fu, Q., Zhou, S., Song, L., Ren, Y., Dong, X., Su, B. and $\mathrm{Li}, \mathrm{C}$. 2016. The mucosal expression signatures of g-type lysozyme in turbot (Scopthalmus maximus) following bacteria challenge. Fish Shellfish Immunol., 54: 612-619. DOI: 10.1016/j.fsi.2016.05.015.

Ghalambor, M., Eslamifar, Z. and Khoshnood, Z. 2020. Biochemical characterisation of lysozyme extracted from common carp Cyprinus carpio. Ecopersia, 8(2): 125-131.

Grove, S., Johansen, R., Reitan, L. and Press, C. M. Immune and enzyme histochemical characterisation of leukocyte populations within lymphoid and mucosal tissues of Atlantic halibut (Hippoglossus hippoglossus). Fish Shellfish Immunol., 20(5): 693-708.

Magnadottir, B. 2006. Innate immunity of fish (overview). Fish. Shellfish Immunol., 20: 137-151. doi: 10.1016/j. fsi.2004.09.006.

Minagawa, S., Hikima, J., Hirono, I. and Aoki, T. 2001. Expression of Japanese flounder cDNA in insect cells. Develop. Comp. Immunol., 25: 439-445. DOI: 10.1016/ s0145-305x(01)00013-1.

Misook, K., Minjeong, P. and Yoonhwa, J. 2012. Purification and characterisation of lysozyme from filipino venus, Ruditapes philippinarum. Food. Sci. Biotechnol., 21: 1463-1468.

Modanloo, M., Soltanian, S., Akhlaghi, M. and Hoseinifar, S. H. 2017. The effects of single or combined administration of galactooligosaccharide and Pediococcus acidilactici on cutaneous mucus immune parameters, humoral immune responses and immune related genes expression in common carp (Cyprinus carpio) fingerlings. Fish Shellfish Immunol., 70: 391-397. doi: 10.1016/j.fsi.2017.09.032.

Nilsen, I. W., Overbo, K., Sandsdalen, E., Sandaker, E., Sletten, K. and Bjornar, M. 1999. Protein purification and gene isolation of chlamysin, a cold active lysozyme-like enzyme with antibacterial activity. FEBS Lett., 464: 153-158. https://doi.org/10.1016/S0014-5793(99)01693-2.

Pabic, L. C., Safi, G., Scrpentini A., Lebel, J., Robin, J. and Koueta, N. 2014. Prophenoloxidase system lysozyme and protease inhibitor distribution in the common cuttlefish Sepia officinalis. Comp. Physiol. B, 172-173: 96-104. doi: 10.1016/j.cbpb.2014.04.009.

Palaksha, K. J., Shin, G. W., Kim, Y. R. and Jung, T. S. 2008. Evaluation of nonspecific immune components from the skin mucus of olive flounder (Paralichthys olivaceus). Fish Shellfish Immunol., 24: 479-488. doi: 10.1016/j. fsi.2008.01.005.

Panigrahi, A., Kiron V., Kobayashi, T., Puangkaew, J., Saoh S. and Sugita, H. 2004. Immune responses in rainbow trout Oncarhyanchus mykiss induced by a potential probiotic bacteria Lactobacillus rhamnosus JCM 1136. Vet. Immunol. Immunopathol., 102: 379-338. doi: 10.1016/j. vetimm.2004.08.006.

Sidhan, V. and Gurnani, S. 1982. Kinetic characterization of rat liver nuclear lysozyme. J. Biosci., 4(2): 191-195.

Subramanian, S., Ross, N. W. and MacKinnon, S. L. 2008. Comparison of antimicrobial activity in the epidermal mucus extracts of fish. Comp. Biochem. Physiol. B, 150(1): 85-92. doi: 10.1016/j.cbpb.2008.01.011.

Uribe, C., Folch, H., Enriquez, R. and Moran, G. 2011. Innate and adaptive immunity in teleost fish: A review. Vet. Med., 56(19): 486-503. 